\title{
PENERAPAN LEMBAR KERJA SISWA (LKS) BERBASIS REALISTIC MATHEMATICS EDUCATION (RME) TERHADAP KEMAMPUAN PENALARAN MATEMATIS SISWA
}

\author{
${ }^{1}$ Hasnaa Indar N
}

\author{
${ }^{1}$ Program Studi Pendidikan Matematika, Fakultas Keguruan dan Ilmu Pendidikan, Universitas \\ Muhammadiyah Sukabumi
}

hasnaaindar@gmail.com

\begin{abstract}
ABSTRAK
Penelitian ini bertujuan untuk mengkaji penerapan Lembar Kerja Siswa (LKS) berbasis Realistic Mathematics Education (RME) terhadap kemampuan penalaran matematis siswa. LKS yang digunakan selama ini belum tentu menuntun siswa untuk aktif membangun pemahamannya sendiri. Maka sangat perlu diterapkan LKS yang dapat menuntun siswa untuk aktif membangun pemahamannya, salah satu inovasinya yaitu dengan menerapkan LKS berbasis RME untuk memberikan kesempatan kepada siswa dalam membangun sendiri pengetahuannya serta dapat mengaplikasikan konsep yang telah dipelajari dalam pemecahan masalah kontekstual. Metode yang digunakan dalam penelitian ini adalah metode kualitatif dengan jenis penelitian kepustakaan dengan pengumpulan informasi dan data secara mendalam melalui berbagai literatur, buku, catatan, serta hasil penelitian sebelumnya yang relevan. Dari hasil tersebut dapat disimpulkan dugaan penerapan Lembar Kerja Siswa (LKS) berbasis Realistic Mathematics Education (RME) mampu meningkatkan kemampuan penalaran matematis siswa pada pokok bahasan persegi panjang. Hal tersebut disebabkan karena beberapa hal, seperti: 1) LKS berbasis RME ini memfasilitasi siswa agar memiliki kebebasan dalam mengkonstruksikan pengetahuan dan pemahaman yang dimiliki. 2) LKS berbasis RME ini juga memfasilitasi siswa dalam peningkatan kemampuan penalaran, berpikir kreatif, keaktifan dalam mengintregasikan masalah sehari-hari untuk menyelesaikan soal. 3) LKS berbasis RME ini dapat memotivasi siswa karena didalamnya berisi kegiatan percobaan untuk menemukan konsep keliling dan luas persegi sehingga dapat membangkitkan motivasi dan semangat siswa dalam belajar. 4) LKS berbasis RME ini memiliki tampilam menarik dan tidak monoton serta langkah-langkah yang terdapat pada LKS dapat mudah dipahami siswa
\end{abstract}

Kata Kunci: Realistic Mathematics Education (RME), Lembar Kerja Siswa (LKS) berbasis RME, Kemampuan Penalaran Matematis

\section{PENDAHULUAN}

Matematika merupakan ilmu dasar yang sangat penting karena sering digunakan dalam menyelesaikan mata pelajaran lain ataupun dalam kehidupan seharihari. Matematika juga dikenal sebagai suatu ilmu pengetahuan abstrak yang karakteristik utamanya adalah pola berfikir yang logis, kritis, sistematis dan konsisten. Mengingat pentingnya pembelajaran matematika, pemilihan strategi dan metode pembelajaran yang sangat tepat di anjurkan kepada guru yang akan memberikan pembelajara dikelas. Pembelajaran matematika di sekolah ditujukan agar siswa memiliki daya nalar yang baik terutama ketika menyelesaikan soal dalam mata pelajaran matematika, maka dari itu kemampuan penalaran memiliki peran yang sangat penting dalam tercapainya tujuan pendidikan matematika di sekolah, karena ketika siswa memiliki kemampuan penalaran yang tinggi akan terlihat lebih mudah dalam memahami dan mengejakan soal matematika. Kemampuan penalaran merupakan suatu kegiatan atau proses berfikir untuk menarik kesimpulan atau membuat pernyataan baru yang didasarkan pada pernyataan sebelumnya dan kebenarannya telah dibuktikan. Penalaran matematis ditujukan agar siswa mampu untuk mengajukan dugaan kemudian menyusun bukti, melakukan manipulasi terhadap permasalahan matematika dan menarik kesimpulan dengan benar dan tepat.

Berkenaan dengan penalaran, National Council of Teacher of Mathematics (NCTM, 2000) mengatakan bahwa saat dalam pelaksanaan pembelajaran matematika, guru harus memperhatikan lima kemampuan matematis, yaitu: koneksi (connection), penalaran (reasoning), komunikasi (communication), pemecahan masalah (problem solving) dan representasi (representation). Maka dari itu salah satu dari kemampuan matematis tersebut, guru memiliki peranan dalam menumbuhkan kemampuan penalaran matematis siswa dalam metode pembelajaran yang dipakai dikelas.

Berdasarkan beberapa hasil penelitian terdahulu menunjukan bahwa kemampuan penalaran matematis siswa belum sesuai dengan yang diharapkan. Menurut Wahyudin (dalam Usniati, 2011) bahwa salah satu kecenderungan yang menyebabkan siswa gagal menguasai dengan baik pokok-pokok bahasan dalam matematika yaitu siswa kurang memahami dan meggunakan nalar yang baik dalam menyelesaika soal yang diberikan. Menurut pendapat Rosmiati (2011) 
yang mengemukakan bahwa rata-rata presentase paling rendah yang dicapai oleh peserta didik Indonesia adalah dalam domain kognitif pada level penalaran yaitu $17 \%$. Presentase jauh dibawah presentase kelulusan international yaitu penalaran $30 \%$. Menurut Desi Gusnarsi, dkk (2017) kemampuan penalaran matematis siswa masih rendah karena dalam proses pembelajaran masih berpusat pada guru yang mengakibatkan siswa cenderung pasif dalam proses pembelajaran, selain itu proses pembelajaran cenderung menggunakan model pembelajarn konvesional yang tidak menekankan guru untuk mengaplikasikan materi pembelajaran matematika dalam kehidupan nyata sehingga mengakibatkan siswa kurang termotivasi untuk memahami matematika.

Dilihat dari rendahnya kemampuan penalaran siswa maka dibutuhkan inovasi pembelajaran yang dapat dijadikan strategi untuk memudahkan siswa dalam menguasai ilmu pengatahuan dan dapat meningkatkan kemampuan penalaran matematis siswa.

Salah satu inovasi pembelajaran untuk meningkatkan kemampuan penalaran matematis siswa adalah diterapkannya model pembelajaran Realistic Mathematics Education (RME). Model pembelajaran RME menitik beratkan pada pembelajaran matematika yang difokuskan pada kehidupan sehari-hari (konstektual) yang memberikan hal nyata untuk diajarkan kepada siswa, maka dari itu banyak kesempatan yang diberikan oleh guru kepada siswa untuk membangun pemahaman siswa itu sendiri. Di Indonesia RME dikenal dengan Pendidikan Matematika Realistik Indonesia (PMRI). PMRI ini merupakan sebuah pendekatan adaptasi dari RME dalam kurikulum Indonesia untuk memperbaiki dan meningkatkan kualitas pendidikan matematika Indonesia. RME memiliki prinsip saat mengajarkan matematika harus disajikan dari hal-hal yang bersifat konstektual, siswa akan lebih memahami materi matematika sehingga siswa tidak akan mengalami kesulitan memahami materi matematika yang bersifat abstrak. Disamping itu ketersediaan bahan ajar yang tepat juga diperlukan untuk memfasilitasi pembelajaran dalam meningkatkan kemampuan penalaran matematis siswa seperti Lembar Kerja Siswa (LKS) berbasis RME.

LKS merupakan suatu perangkat pembelajaran yang terdiri dari sekumpulan kegiatan, masalah atau soal yang dikerjakan siswa selama proses pembelajaran. Menurut Depdiknas (2008:13) Lembar Kerja Siswa (student worksheet) adalah lembaran-lembaran berisi tugas yang harus dikerjakan oleh siswa. Lembar kegiatan biasanya berisi petunjuk, langkah-langkah untuk menyelesaikan suatu tugas. Dalam penggunaan
LKS berbasis RME siswa didorong untuk aktif dalam mengkonstruk pengetahuannya. Selain itu, LKS memfasisilitasi siswa untuk saling berdiskusi dan saling bertukar ide atau gagasan dengan temannya. Menurut Richard dan Tomlinson (dalam Nurjanah) menyatakan bahwa bahan ajar dan lembar kerja yang ideal dan efektif adalah perangkat yang dapat memberikan informasi dan pengalaman belajar. Keefektifan suatu bahan ajar biasanya dilihat dari potensial efek berupa kualitas hasil belajar, peningkatan kemampuan penalaran matematis, sikap dan motivasi siswa.

Berdasarkan permasalahan diatas, tujuan diterapkannya pembelajaran matematika dengan model RME adalah untuk meningkatkan kemampuan penalaran matematis siswa. Tujuan dari penelitian ini adalah untuk mengatahui efektifitas penerapan Lembar Kerja Siswa Realistic Mathematics Education (RME) terhadap kemampuan penalaran matematis siswa.

\section{Kemampuan Penalaran Matematis Siswa}

Menurut Suriasumantri (dalam Mulia, 2014) penalaran adalah suatu proses berfikir dalam menarik suatu kesimpulan yang berupa pengetahuan. Selain itu menurut Kurniawati (2006) penalaran sering diartikan sebagai cara berfikir yang merupakan penjelasan dalam upaya memperlihatkan hubungan antara dua hal atau lebih yang diakui kebenarannya dengan langkahlangkah tertentu yang berakhir dengan suatu kesimpulan hasil. Dalam kemampuan penalaran matematis dapat membantu siswa dalam menyimpulkan dan membuktikan suatu pernyataan, membangun gagasan baru, sampai pada menyampaikan masalah-masalah dalam matematika.

Dalam penelitian ini, indicator kemampuan penalaran matematis yang digunakan adalah indicator menurut Romadhina (2007) yaitu:

1. Menyajikan pernyataan matematika secara lisan, tertulis, gambar dan diagram.

2. Menngajukan dugaan.

3. Melakukan manipulasi matematika.

4. Menarik kesimpulan, menyusun bukti, memberikan alasan atau bukti terhadap beberapa solusi.

5. Menarik kesimpulan dari pernyataann.

6. Memeriksa keshohihan argument.

7. Menentukan pola atau sifat dari gejala matematis untuk membuat generalisasi.

\section{METODE}

Penelitian ini menggunakan metode kualitatif dengan jenis penelitian kepustakaan Penelitian kepustakaan merupakan suatu jenis penelitian yang digunakan dalam pengumpulan informasi dan data 
secara mendalam melalui berbagai literatur, buku, catatan, serta hasil penelitian sebelumnya yang relevan, untuk mendapatkan jawaban dan landasan teori mengenai masalah yang akan diteliti.

\section{HASIL DAN PEMBAHASAN}

Adapun hasil penelitian yang akan dipaparkan pada bagian hasil dan pembahasan adalah kemampuan penalaran matematis siswa pada materi segitiga dan segiempat pada subbab persegi panjang dengan menerapkan Lembar Kerja Siswa berbasis Realistic Mathematics Education (RME). Menurut Desi Gusnari, dkk (2017) pembelajaran dengan model RME dapat meningkatkan kemampuan penalaran matematis siswa yang dapat terlihat dari hasil tes kemampuan penalaran matematis siswa berupa pretest dan posttes yang memuat empat indicator kemampuan penalaran matematis siswa, yaitu: (1) kemampuan menyajikan pernyataan matematika secara lisan, tertulis, gambar dan diagram, (2) kemampuan mengajukan dugaan, (3) kemampuan melakukan manipulasi matematika dan (4) menarik kesimpulan dari pernyataan. Berdasarkan penelitian tersebut, hal ini juga sesuai dengan kelebihan dari RME yang telah dikemukakan oleh Asmin (dalam Ningtias,2014:18) yang menyatakan bahwa suasana dikelas dalam proses pembelajaran dengan Realistic Mathematics Education (RME) menjadi menyenangkan, karena dengan menggunakan masalah kontekstual sehingga dapat meningkatkan kemampuan penalaran siswa dan ketertarikan siswa dalam belajar matematika.

Agar lebih efektif, dalam penerapan model RME ini perlu dibantu dengan suatu bahan ajar. Menurut Fajar dan Nur (2010) bahan ajar yang menggunakan permasalahan realistic bertujuan untuk mendorong atau memotivasi siswa berfikir kritis, kreatif dan inovatif serta siswa interaktif dalam belajar. Bahan ajar yang digunakan dalam penelitian ini adalah berupa Lembar Kerja Siswa (LKS) berbasis RME. Berdasarkan hasil penelitian Nurjanah siswa lebih tertarik menggunakan LKS dari pada buku paket, hal ini dikarenakan dalam buku paket yang digunakan siswa terlalu banyak penjelasan teori sehingga siswa kurang termotivasi dan kebingungan saat belajar matematika. Namun LKS yang digunakan selama ini belum tentu menuntun siswa untuk aktif membangun pemahamannya sendiri selain itu LKS yang digunakan juga kurang menarik, kertasnya buram dan masih membingungkan siswa karena petunjuk kerja yang sulit dipahami dan kurang jelas. Berdasarkan penelitian tersebut, maka perlu diterapkannya LKS berbasis RME yang dapat menarik siswa. Dalam LKS berbasis RME ini siswa akan melakukan penemuan kembali secara terbimbing.

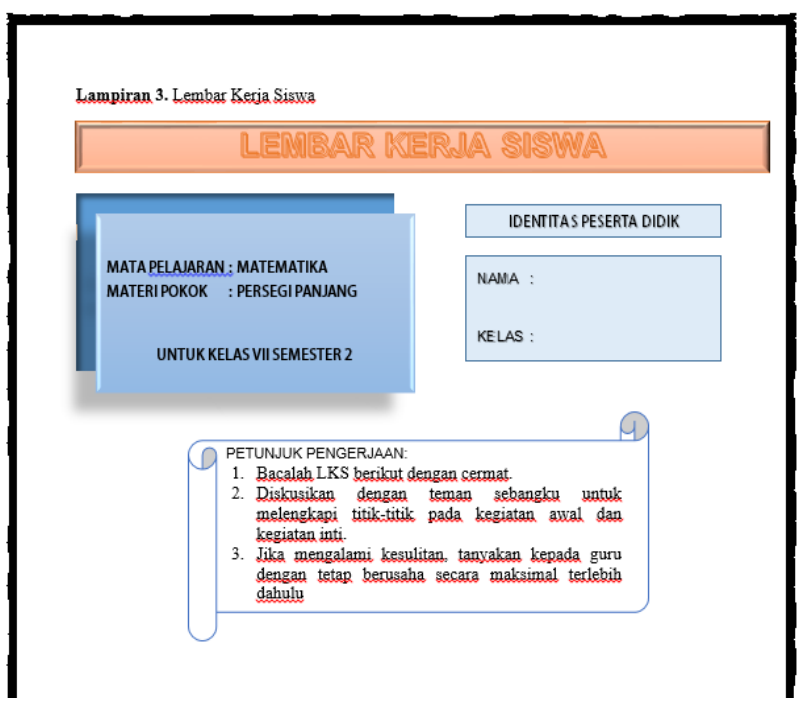

Gambar 1. Layout Halaman Depan LKS

Gambar diatas adalah halaman pertama yang terdapat pada LKS berbasis RME, dihalaman pertama ini sudah jelas bahwa LKS disusun dengan pewarnaan yang menarik agar tidak membosankan saat dipelajari oleh siswa. Selain itu didalamnya terdapat petunjuk pengerjaan yang jelas dan dapat dipahami oleh siswa dengan mudah agar tidak ada lagi siswa yang kebingungan dalam pengerjaannya. Untuk kegiatan awal dan kegiatan inti pada LKS ini dikerjakan secara berkelompok sesuai dengan teman sebangku siswa, pada bagian ini siswa dilatih untuk bekerja sama dan saling menukar pendapat antar individu. Sedangkan untuk bagian tugas individu dikerjakan oleh masingmasing siswa, tujuan pada bagian ini adalah untuk menguji seberapa paham siswa dalam menentukann konsep matematika, serta menguji peningkatan kemampuan penalaran matematis siswa dalam memecahkan soal-soal yang terdapat pada tugas individu tersebut

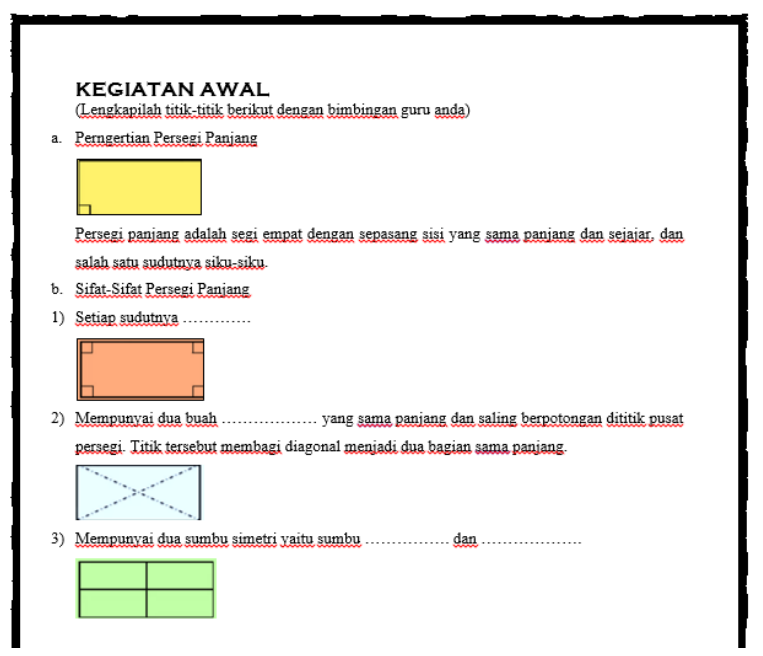

Gambar 2. Layout kegiatan awal LKS 
Dari gambar diatas, pada kegiata awal LKS guru merangsang pengetahuan awal siswa dengan cara mendemonstrasikan sebuah persegi panjang yang telah disiapkan sebelumnya, lalu guru mengarahkan siswa untuk menemukan pengertian dan juga sifat-sifat persegi panjang dengan mengisi titik-titik didalam LKS yang telah dibagikan. Pada kegiatan awal ini guru berusaha mengingatkan kembali materi yang telah dipelajari agar siswa dapat mempergunakan kemampuan awalnya. Pada bagian ini juga bertujuan agar guru mengetahui sejauh mana materi atau bahan pelajaran yang sudah dikuasai oleh siswa pada pertemuan sebelumnya.

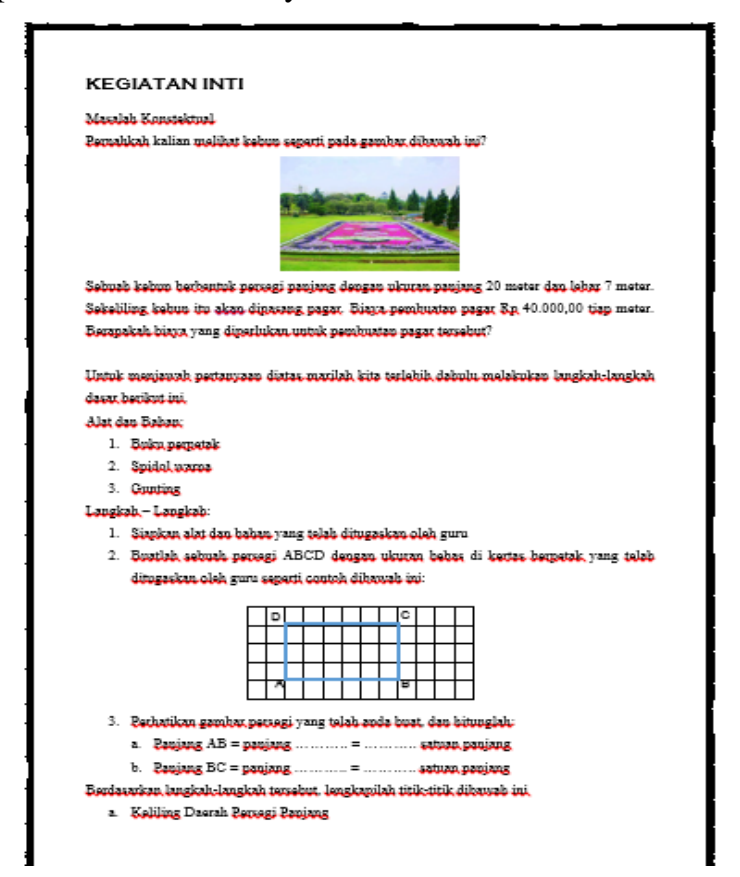

Gambar 3. Layout Kegiatan Inti LKS

Dari gambar ketiga ini, siswa melakukan penemuan kembali secara terbimbing sesuai prinsip dasar RME menurut Freudhental yaitu Guided reinvention and progressive mathematizing, prinsip ini memberikan kesempatan kepada siswa untuk menemukan ide matematika melalui proses belajar dengan menggunakan situasi yang mengandung konsep matematika dan nyata bagi siswa. Dalam proses penemuan kembali pembelajaran menjadi efektif serta siswa dapat membentuk pengetahuannya sendiri. Dalam proses ini juga perlu adanya bimbingan guru sehingga proses penemuan kembali dapat dilakukan secara terbimbing (guided re-invention). Dalam melakukan bimbingan, guru dapat menggunakan perangkat pembelajaran melalui diskusi dan dialog dengan siswa sehingga siswa dilatih aktif dalam pembelajaran.
Dalam kegiatan ini diawali dengan diberikannya masalah kontekstual yang berkaitan dengan kehidupan sehari-hari. Dengan adanya kaitan dalam kehidupan sehari-hari maka siswa akan lebih termotivasi saat mengikuti pembelajaran matematika. Masalah ini akan dipecahkan oleh siswa secara berkelompok yang sudah dibagi oleh guru sebelumnya. Namun sebelum memecahkan masalah kontekstual tersebut, siswa diarahkan untuk melakukan langkah-langkah yang terdapat pada LKS. Langkah-langkah tersebut bertujuan agar siswa tidak bingung saat melakukan pengerjaannya. Dalam langkah-langkah tersebut guru mengarahkan siswa untuk membuat media/model yang bisa dijadikan tempat mengekspresikan ide-ide yang mereka miliki kedalam kelompok tersebut, seperti siswa diarahkan untuk membuat suatu persegi panjang di sebuah kertas berpetak dengan sebuah spidol berwarna. Lalu siswa diarahkan untuk menghitung panjang dan lebar nya dengan cara menghitung satuan petak pada kertas berpetak tersebut.

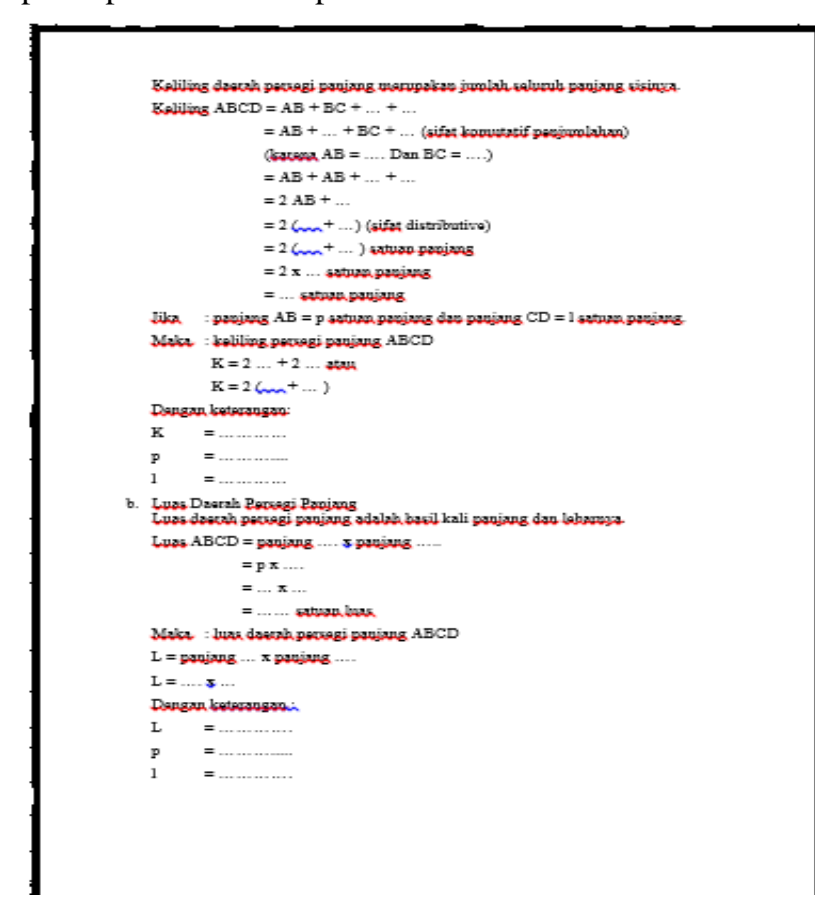

Gambar 4. Layout Penemuan Luas dan Keliling

Seperti yang terlihat pada gambar keempat, setelah siswa menghitung panjang dan luas persegi panjang yang telah dibuatnya dari kertas berpetak, selanjutnya siswa dituntut untuk menemukan konsep keliling dan luas persegi panjang dengan mengisi isian yang terdapat pada LKS. Maka dalam hal ini kegiatan pembelajaran yang tercipta dapat membangkitkan semangat siswa dan dapat meningkatkan potensi kemampuan penalaran matematis siswa, siswa juga akan lebih banyak menuangkan ide mereka untuk menemukan strategi dalam memecahkan masalah. Hal ini sesuai dengan hasil dari penelitian Alek 
Rimbayanto dan Nining Setyaningsih (2015) bahwa siswa terlihat lebih komunikatif dan kreatif dalam mengikuti pembelajaran. Adapun menurut Subagio (2010) bahwa siswa terlibat dalam berbagai bentuk kegiatan pembelajaran yang dapat mengembangkan pemahaman dan kemampuan bernalar siswa melalui berbuat atau melakukan dan mencipta dengan mengikuti langkah-langkah yang sudah disediakan.

Pada kegiatan inti ini, guru memberikan kesempatan kepada siswa terlebih dahulu untuk mengemukakan ide-ide dan konsep berdasarkan pemahaman siswa dan apa yang ada di sekeliling siswa sehingga siswa tertarik untuk belajar. Lalu guru akan memberikan jawaban dari pertanyaan-pertanyaan yang dilemparkan siswa sehingga pada tahap ini akan terjadinya umpan balik antara siswa dan guru.

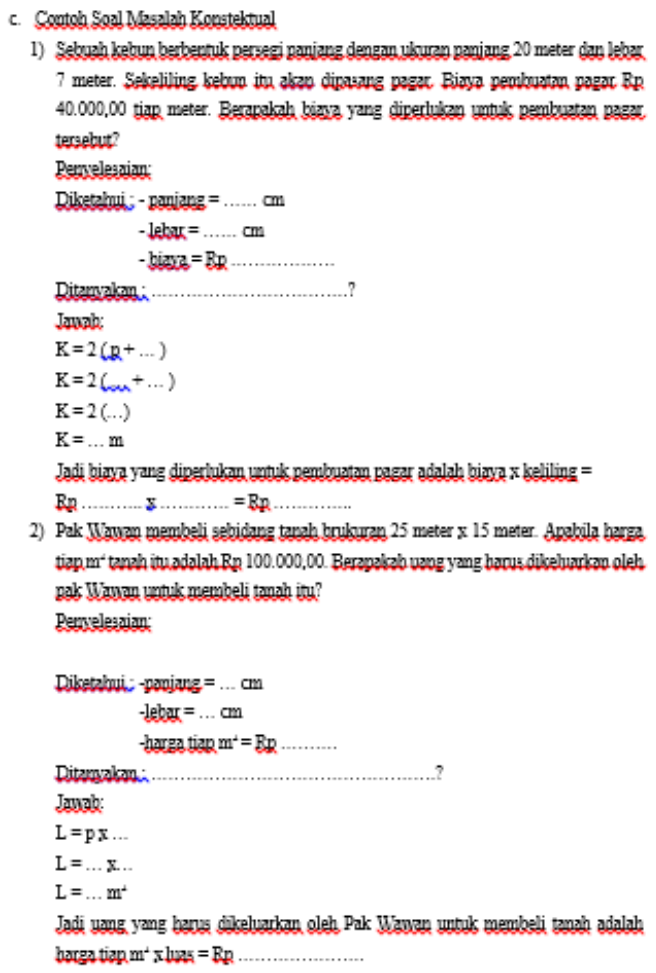

Gambar 5. Contoh Permasalahan

Pada contoh permasalahan diatas, siswa dilatih untuk meningkatkan kemampuan penalaran matematis dengan memecahkan masalah yang berkaitan dengan kehidupan sehari-hari. Masalah tersebut disajikan untuk dilengkapi dengan langkah-langkah dalam menyelesaikan masalah dari informal menuju formal, sesuai dengan prinisp RME menurut Freudenthal yaitu Self-Developed Models merupakan jembatan bagi siswa dari situasi real menuju situasi konkrit atau dari informal ke formal. Pertama adalah model of situasi yang dekat dengan alam pemikiran siswa dan digeneralisasi menjadi model for situasi dari formal matematika. Hal ini diperlukan untuk memfasilitasi siswa dalam meningkatkan kemampuan melakukan improvisasi penyelesaian masalah dan kemampuan penalaran matematis siswa sehingga siswa mampu menemukan konsep matematika secara terstruktur.

Selain itu, dalam kegiatan ini juga guru mendampingi dan mendorong serta memberi kesempatan kepada siswa agar mereka berani untuk mengungkapkan ide dan menyampaikan strategi dalam memecahkan masalah tersebut kepada teman-teman yang lainnya untuk selanjutnya ditanggapi, hal tersebut sesuai dengan karaketristik RME menurut Traffers yaitu interactifity, maksudnya adalah proses belajar yang dilakukan siswa tidak hanya proses pembelajaran secara individu, tetapi juga merupakan proses pembelajaran secara sosial. Adapun menurut Marpaung (2001:3) bahwa siswa harus aktif tidak boleh pasif, siswa harus aktif mengontruksi sendiri pengetahuan matematika, siswa diberi kebebasan untuk mengekspresikan ide yang telah dipikirkannya, menyelesaikan masalah menurut pengetahuannya, mengkomunikasikannya dan belajar dari temannya sendiri.

Setiap masalah yang terdapat didalam LKS berkaitan dengan kehidupan sehari-hari yang diselesaikan oleh siswa berdasarkan konsep matematika yang telah ditemukan sebelumnya.

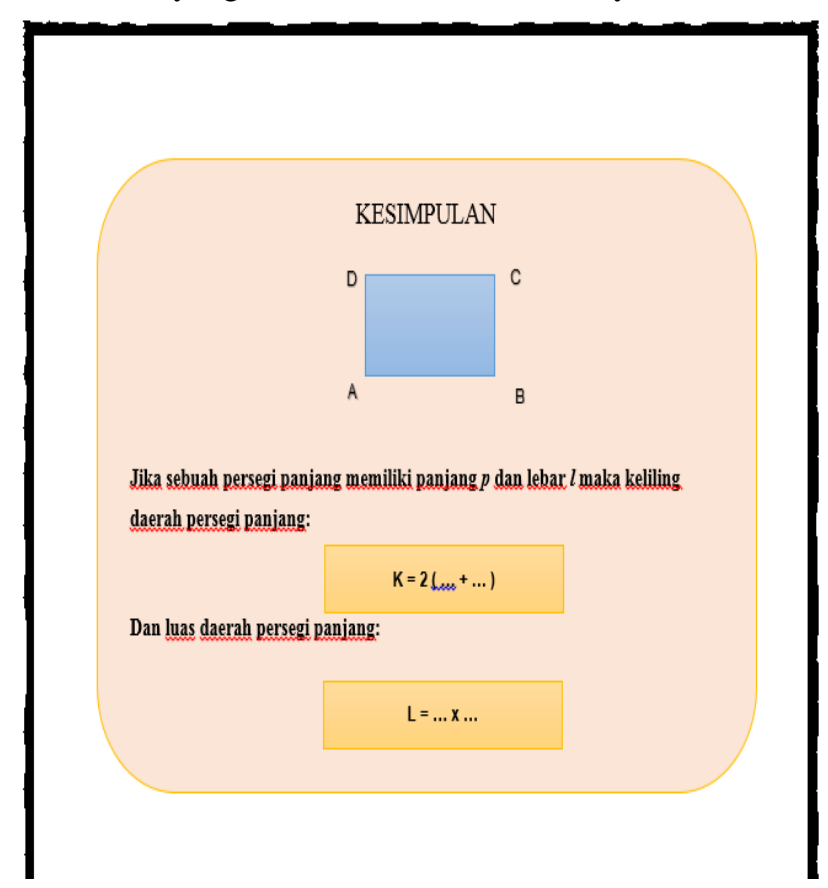

Gambar 6. Layout Kesimpulan

Setelah siswa melalui berbagai tahap pengerjaan LKS berbasis RME ini, selanjutnya siswa menyimpulkan apa yang telah siswa temukan sebelumnya. Tujuan dari kegiatan ini adalah agar siswa 
memperoleh pemahaman yang lebih dalam terkait konsep luas dan keliling persegi panjang.

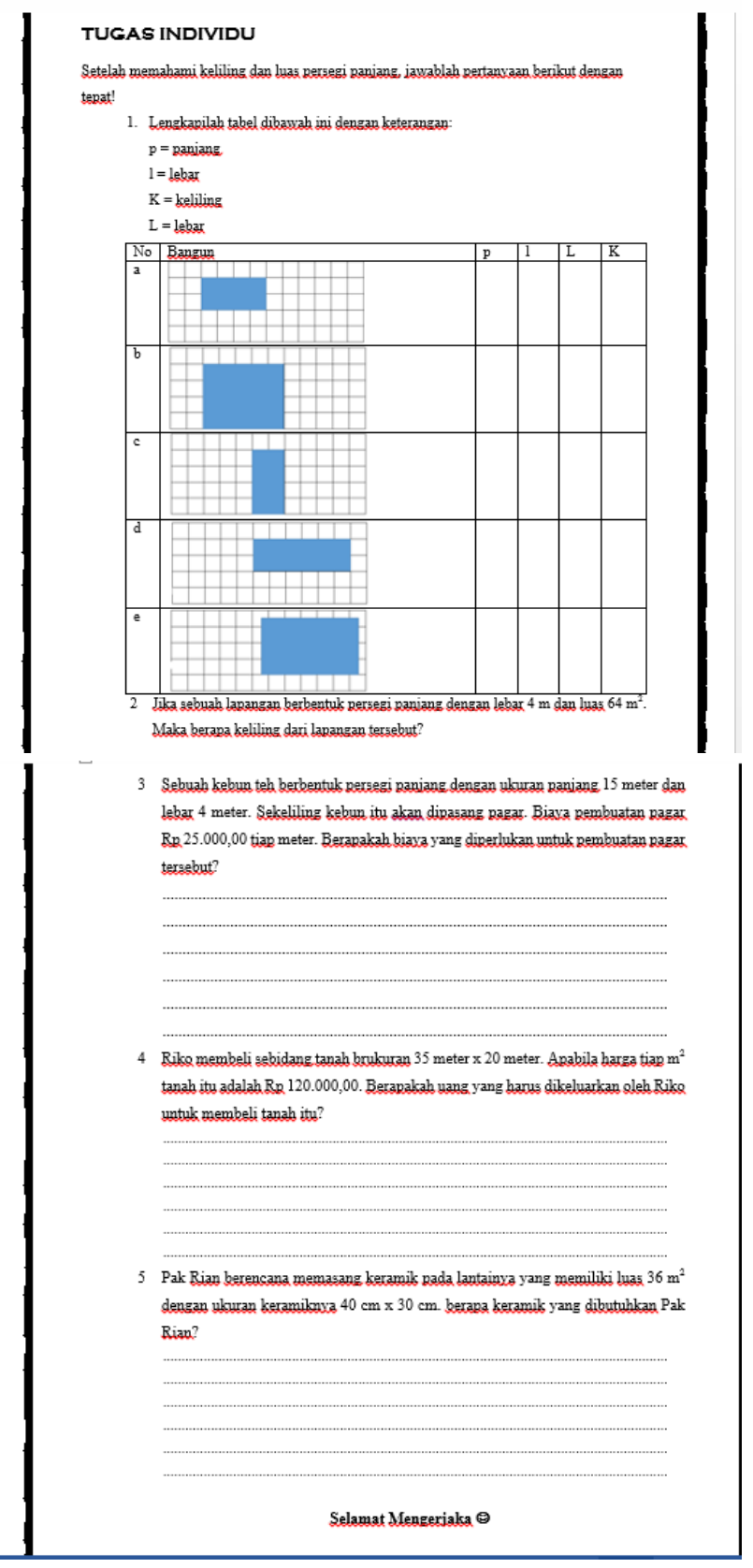

Gambar 7. Tugas Individu Siswa

Tugas individu ini digunakan untuk mengetahui peningkatan kemampuan penalaran matematis siswa. Siswa dikatakan mampu jika siswa dapat melakukan manipulasi matematika dalam membuat generalisasi, dapat membuat pernyataan matematika dan menjelaskan gagasan atau menuyusun bukti serta dapat menggunakan penalaran pada pola dan sifat. Berdasarkan hal tersebut, terdapat penjelasan teknis Peraturan Dirjen Dikdasmen Depdiknas Nomor 506/C/Kep/PP/2004 tanggal 11 November 2004 yang dikutip dari (Sri Wardani 2005:1) tentang penilaian perkembangan siswa dicantumkan indicator dari kemampuan penalaran sebagai hasil belajar matematika yaitu siswa mampu menyajikan pernyataan matematika secara lisan, tertulis, gambar, dan diagram. Kemampuan siswa mengajukan dugaan, kemampuan ini merupakan kemampuan siswa dalam meumuskan berbagai kemungkinan pemecahan sesuai dengan pengetahuan yang dimilikinya. Kemudian siswa mampu memanipulasi matematika, kemampuan manipulasi matematika merupakan kemampuan siswa dalam mengerjakan atau menyelesaikan suatu permasalahan dengan menggunakan cara sehingga tercapai tujuan yang dikehendaki. Lalu siswa dapat menarik kesimpulan dari suatu pernyataan yang memberdayakan pengetahuannya untuk menghasilkan sebuah pemikiran. Selanjutnya siswa mampu memeriksa keshahihan suatu argument yang menghendaki siswa agar mampu menyelidiki tentang kebenaran dari suatu pernyataan yang ada. Terakhir siswa mampu menemukan pola atau sifat dari gejala matematis generalisasi. Oleh karena itu dengan menggunakan Lembar Kerja Siswa berbasis RME diharapkan dapat meningkatkan kemampuan penalaran matematis siswa.

Dalam pembelajaran menggunakan penerapan LKS berbasis RME terhadap kemampuan penalaran matematis ini merupakan bahan ajar yang didalamnya terdapat pertanyaan-pertanyaan dan soal-soal yang harus dilengkapi serta dikerjakan oleh siswa, selain itu terdapat pula petunjuk dan langkah-langkah yang akan memudahkan siswa untuk menyelesaikan permasalahan yang terdapat pada LKS. Didalam LKS ini juga berisikan kegiatan pecobaan sehingga dapat membantu guru dalam membimbing siswa dalam kegiatan percobaan untuk menemukan konsep serta dapat membantu siswa untuk melakukan penyelidikan atau penemuan. Tampilan dari LKS ini juga sangat menarik dan tidak monoton seperti yang dikeluhkan siswa pada penelitian sebelumnya sehingga siswa akan termotivasi dalam pembelajaran dan dapat membantu untuk meningkatkan kemampuan penalaran matematis siswa.

\section{PENUTUP}

\section{Simpulan}

Berdasarkan hasil penelitan dan pembahasan yang telah dipaparkan pada bagian sebelumnya, maka secara umum dapat disimpulkan bahwa penerapan Lembar Kerja Siswa (LKS) berbasis Realistic Mathematics Education (RME) mampu meningkatkan kemampuan penalaran matematis siswa pada pokok bahasan persegi panjang. Hal tersebut disebabkan karena beberapa hal, seperti: 
1. LKS berbasis RME ini memfasilitasi siswa agar memiliki kebebasan dalam mengkonstruksikan pengetahuan dan pemahaman yang dimiliki.

2. LKS berbasis RME ini juga memfasilitasi siswa dalam peningkatan kemampuan penalaran, berpikir kreatif, keaktifan dalam mengintregasikan masalah sehari-hari untuk menyelesaikan soal.

3. LKS berbasis RME ini dapat memotivasi siswa karena didalamnya berisi kegiatan percobaan untuk menemukan konsep keliling dan luas persegi sehingga dapat membangkitkan motivasi dan semangat siswa dalam belajar.

4. LKS berbasis RME ini memiliki tampilan yang menarik dan tidak monoton serta langkah-langkah yang terdapat didalam LKS pun mudah dipahami oleh siswa.

\section{Saran}

Berdasarkan kesimpulan diatas, maka terdapat beberapa saran sebagai berikut:

1. Penerapan Lembar Kerja Siswa (LKS) berbasis Realistic Mathematics Education (RME) dapat menjadi salah satu solusi diantara alternatif dalam pembelajaran matematika untuk meningkatkan kemampuan penalaran matematis siswa.

Iltavia. 2017. Efektivitas Lembar Kerja Siswa (LKS) Berbasis Pendekatan Realistics Mathematics Education (RME). 11(76): 77-82

Nurjanah. 2018. Pengembangan Lembar Kerja Siswa (LKS) Berbasis POE (Predict- Observe-Explain) Melalui Pendekatan Methaporal Thinking Berorientasi Kemampuan Penalaran Matematis Siswa SMP [Skripsi]. Lampung: Universitas Islam Negeri Raden Intan Lampung.

Rahmawati Fatimah. 2019. Peningkatan Kemampuan Penalaran Siswa Dalam Pembelajaran Matematika
2. Saat penyampaian materi pada subbab persegi panjang, perlu dicoba dengan menerapkan LKS berbasis RME untuk meningkatkan kemampuan penalaran matematis siswa atau kemampuan matematis lainnya.

3. Kreativitas guru dalam menyajikan pembelajaran matematika dengan menerapkan LKS berbasis RME yang lebih menarik tidak akan menimbulkan kebosanan bagi siswa saat pembelajaran berlangsung.

4. Guru sebaiknya memberikan arahan yang jelas kepada siswa agar tidak ada kebingungan saat pembelajaran dengan menggunakan LKS berbasis RME serta memantau aktivitas siswa selama pembelajaran berlangsung.

\section{DAFTAR PUSTAKA}

Afriansyah Ekasatya Aldila. 2016. Makna Realistik Dalam RME dan PMRI. 2(2): 96-104

Astuti Erni Puji. 2017. Penalaran Matematis Dalam Menyelesaikan Masalah Matematika Siswa SMP. 3(2): 83-91

Gusnarsi Desi, Citra dan Rika. 2017. Pengaruh Model Pembelajaran Realistic Mathematics Education (RME) Terhadap Kemampuan Penalaran Matematis Siswa Pada Materi Lingkaran Kelas VIII. 2(1): 122-126.

Melalui Pendekatan Realistic Mathematics Education (RME) Berbasis Number Head Together (NHT) [Skripsi]. Surakarta: Universitas Muhammadiyah Surakarta.

Ramdani Ilyas. 2014. Pengembangan Bahan Ajar Dengan Pendekatan Pendidikan Matematika Realistik Indonesia (PMRI) Untuk Memfasilitasi Pencapaian Literasi Matematika Siswa Kelas VII [Skripsi]. Yogyakarta: Universitas Negeri Yogyakarta. 